\title{
GENERIC DRUGS - DECREASING COSTS AND ROOM FOR INCREASED NUMBER OF KIDNEY TRANSPLANTATIONS
}

\section{Goce Spasovski}

University Department of Nephrology, Medical Faculty, University of Skopje, Macedonia

Corresponding Author: Prof. Goce Spasovski, University Department of Nephrology, Medical Faculty University of Skopje, Vodnjanska 17, 1000 Skopje, R. Macedonia Mob. phone: +389 70268 232, Fax: +389 23220935 , or +38923231 501, E-mail: spasovski.goce@gmail.com

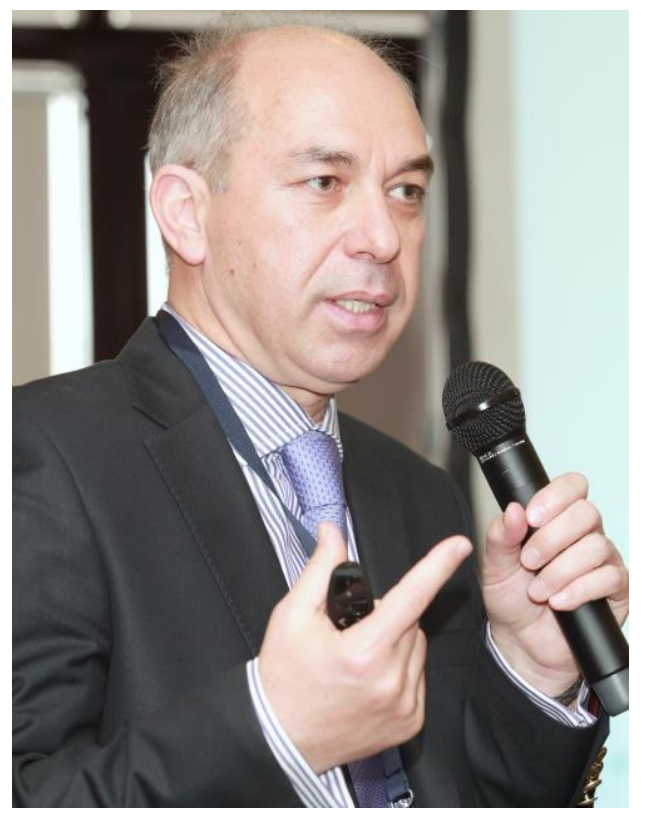

\begin{abstract}
Kidney transplantation is the best treatment option in comparison to dialysis, although patients are obliged to receive life-long medical treatment with immunosuppressive drugs (ISDs) for prevention of the graft rejection. Such immunosuppressive treatment may be costly and associated with multiple adverse effects. Since costs are viewed as one of the major constraints for the increasing number of transplantation, the use of generic ISDs may decrease the overall cost of transplantation and raise the possibility for its further development.

An ideal ISD should have the security margin between toxic and therapeutic dose, and prevent development of acute or chronic rejection of the transplanted kidney. This is particularly important for drugs with a "narrow therapeutical index" (NTI), where small differences in dose or concentration lead to dose and concentration-dependent, serious therapeutic failures and/or adverse drug reactions. The NTI generic drug is approved if within $90 \%-112 \%$ of the area under the curve of the original product the pharmacokinetics fulfills the strict criteria of pharmaceutical equivalence and bioequivalence. Every generic has to be proven to be bioequivalent to the innovator product, and not to other generic products because of the possible generic "drift". Thus, the generic ISDs may be economically attractive, but theoretically, they may pose a risk to transplant patients. Such risks may be reduced if a long-term clinical studies showing cost-effectiveness of generic ISDs in de novo and prevalent transplant patients for every new generic ISD are performed.
\end{abstract}


In conclusion, the increased number of solid organ transplantation goes in line with the increased health care expenditure for ISDs. The generic immunosuppressants could be a possible solution if safely substituted for innovator products or other generic drug of choice. The substantial cost reduction needs to be redirected into organ donation initiatives so that more patients can benefit from the further increase in transplantation.

Key words: Kidney transplantation, immunosuppressive treatment, generic drugs, narrow therapeutical index.

\section{Introduction}

Kidney transplantation is the best treatment in patients with chronic kidney disease (CKD) requiring renal replacement therapy (RRT) [1]. Although with improved quality of life and survival compared to any other RRT modality the kidney transplant patients are obliged to receive life-long medical treatment with immunosuppressive drugs (ISDs) for prevention of the graft rejection. On the other hand, such immunosuppressive treatment may be costly and associated with multiple adverse effects. In addition, the growing number of transplantation is associated with the greatest proportion of expenditures from the health insurance funds compared to any other therapeutic category [2]. Thus, it seems inevitable to bring cheaper generic ISDs on the market as a possibility to further expand the transplantation field with growing number of patients [3]. In this regard, the professionals are faced with the requirement considering the cost-efficiency of ISDs treatment along with the promotion of clinical excellence according to allocated healthcare resources. There are many dilemmas when and how to justify the use of brand-name drugs differentiating it from the offered policy for the lowest drug price imposed by the health system that may be also ethically questionable [4].

There are a couple of definitions for generic drugs. According to the U.S. Food and Drug Administration (FDA): A generic drug (generic drugs, short: generics) is a drug defined as "a drug product that is comparable to a brand/reference listed drug product in dosage, form strength, quality and performance characteristics and intended use" [5]. The generic drug should be with the same active ingredient as a brand-name drug, but the excipients can be different, that could affect the absorption of the active ingredient and lead to a different blood concentration. Another definition by World Health Organization (WHO) is: A generic drug is a pharmaceutical product, usually intended to be interchangeable with an innovator company and marketed after the expiry date of the patient or other exclusive rights [6]. The definition by the free dictionary: A medication sold under its generic name - usually legal only after the patent has expired or if no patent was issued for the substance [7]. Nevertheless, the generic drugs are usually less expensive than proprietary medications. Finally, the common issue through all definitions is the comparability of the brand and generic drug which per se means a possible interchangeability.

\section{Drug testing and approval}

Pharmaceutical industry research and development (R\&D) worldwide is important for the patients' benefits from the new drugs developed, but also for the economy growth and future competitiveness in an advancing global economical perspective. Despite the direct employing of around 700.000 people with generation of a couple of times higher employment indirectly, this giant European pharmaceutical sector is today faced with real challenges. In addition to the regulatory hurdles and escalating R\&D costs, it has been severely hit by the impact of fiscal austerity measures introduced by governments across Europe and the surge of generic drugs on the market. Although primarily considered to save health-care budget neither the social security nor the patients benefit and it deprives the industry of additional resources to fund further R\&D. Since all new medicines introduced into the market result in at least 10 years long, costly and risky $R \& D$ procedure, there is a decreasing trend in the pharmaceutical growth in Europe, USA and Japan and a reduced number of innovative drugs in the last decade [8]. Additionally, at least half of the market share of generics today is already overtaken in the developed countries with even greater proportion in the markets of emerging economies of Brazil and China. 
The regulation for the new drug license is very strict all over the world, but much less costly and lengthy for generics. Namely, generics should be the same pharmaceutical type, with the same qualitative and quantitative composition, equivalent clinical efficacy and safety and also bioequivalent with the brand name drug. Bioequivalent in fact means that the rate and extent of the active ingredient is available at the site of drug action, i.e. presented with similar drug concentration-time profiles in the blood. Nevertheless, the prescription of generic drugs nowadays remains still controversial. The main concern is that the bioequivalence acceptability range could widely differ leading to a possible generic drift, especially in various group of patients in terms of age and medical conditions. Even more important may be the ethical issue related to the prescription of such generic drugs. Patients assume them less safe and less efficient, especially for elderly and children because of their existing comorbidities and concomitant use of many other drugs [9]. Moreover, the different outlook may lead to a confusion and wrong use of the drug, while some inactive ingredients may be a cause even for intolerance (lactose, gluten, tartrasin etc.).

\section{Immunosuppressive drugs in Kidney transplantation}

A precautious drug use is especially required when there is a specific and expensive treatment such as kidney transplantation per se, accompanied with the cost related to the maintenance therapy. An ideal ISD should have the security margin between toxic and therapeutic dose, and a selective effect upon lymphoid cells. Moreover, it should not cause over immunodepression and either infectious problems (bacterial, virological and fungal) or development of de novo cancers. On the other hand, ISD should prevent development of acute or chronic rejection of the transplanted kidney. It is reported that $25 \%$ of grafts fail to survive at 5 years and around $50 \%$ at 10 year post transplantation [10]. It is still controversial whether CNI nephrotoxicity [11], non-adherence [12], and also variability of the drugs used [13] play the main role as underlying risk factors for such graft survival. Moreover, when short- and long-term graft survival estimates between $\mathrm{Eu}$ - rope and the United States were compared, equal short-term but consistently and substantially higher long-term survival in Europe was observed [11]. This could not have been explained by differences in patient characteristics, but the policy differences between Europe and the United States in coverage for long-term immunosuppressive medication may have influenced the survival patterns. Thus, the generic ISDs may be economically attractive, but theoretically, they may pose a risk to transplant patients. Such risks may be reduced if a longterm clinical studies showing cost-effectiveness of generic ISDs in de novo and prevalent transplant patients for every new generic ISD are performed.

This is particularly important for drugs with a "narrow therapeutical index" (NTI), or "critical dose drugs". These drugs are defined as "drugs where comparatively small differences in dose or concentration lead to dose and concentration-dependent, serious therapeutic failures and/or serious adverse drug reactions" [14]. Four of the ISDs used in kidney transplantation are NTI drugs: cyclosporine, mycophenolate, tacrolimus and sirolimus requiring close monitoring of the concentration levels until optimal therapeutic effect is achieved. In order to be approved the NTI generic drug has to be within $90 \%$ to $112 \%$ of the area under the curve (AUC) of the original product pharmacokinetics fulfilling the strict criteria of pharmaceutical equivalence and bioequivalence. Hence, although bioequivalent with the original product, generic ISDs are considered non-freely substitutable because of the eventual consequences within small differences in their blood concentration. In addition, in cases of different generic ISDs every generic has to be proven to be bioequivalent to the innovator product, and not to other generic products [15]. This is important because of the possible generic "drift", as a generic at one end of the acceptable range of the AUC might not be bioequivalent to another generic at the other end of the acceptable range [16]. This is an issue that transplant professionals are concerned in cases of uncontrolled substitutions (attending nephrologist not informed), that may lead towards under- or over-immunosuppression caused by the generic drift accompanied with possible detrimental complications [17]. 


\section{Generics - clinical considerations}

After introduction of the ISDs in US, the first experience was controversial reporting higher incidence of acute rejection in patients on generic compared to the brand-name cyclosporine mainly because of a higher intra-patient variability of the generic [5]. Although, the generic drug has the same active ingredient as a brand-name drug, various excipients may affect the absorption of the active substance and lead to a variability in blood concentration. Such variability in the trough levels and clearance of either cyclosporine [18] or tacrolimus has been associated with significantly higher incidence of acute rejections and worsening of the graft function [19] and long-term graft failure [20]. Generics may also cause additional confusion because of the various shapes, color or taste and thus, increase the non-adherence by the attending clinicians. The major role of non-adherence was confirmed in a prospective, kidney biopsy based study with predominant findings of antibody mediated or mixed with cell mediated rejection that in $47 \%$ of cases was associated with non-adherent patients [21]. At present, there are only short-term evaluation results showing non-inferior graft survival when original and generic cyclosporine [22] or tacrolimus $[23,24]$ from pharmaceutical companies with long-lasting tradition were compared. The need for a high quality data showing bioequivalence and clinical efficacy of generic immunosuppressants in solid organ transplants has also been confirmed in the recent systematic review and meta analysis [25]. The insufficient evidence leads to vague or at least an ambiguous conclusion that generics are equivalent to innovator immunosuppressants, but at the same time no data could firmly suggest that generics are not equivalent and therefore unsafe. On the other hand, possible RCTs are unlikely to be performed as a matter of required time and related costs that could not be remunerated latter for generic drugs. Thus, well conducted bioequivalence studies on transplant recipients are the only possible alternative. Finally, any change of the ISDs from innovator to generic or from one to another generic formulation should be closely monitored under the supervision of attending physician. Importantly, the costs of the more frequent drug monitoring and visits to the clinics, travel to hospital and lost wages, need to be taken into account in order to have the overall costs related to the generic substitution of the innovative drugs [26].

Among the other issues related to the generic ISDs treatment is the non-uniformity of their use across various countries. Hence, a need for harmonization is preferred as guidance for a safe and efficacious drug use all over the world. Whenever possible, the professional associations (societies) should provide an opinion or position statement on whether or how their members should use generic ISDs. Thus, the Canadian Society of Transplantation recommended an extreme caution asking for bioequivalence demonstrated also in transplant recipients and in subpopulations known to have a high variability in blood concentration [27]. Also, the American Society of Transplantation endorsed prescription of generic ISDs as safe but only in low-risk transplant recipients, strongly supporting the bioequivalence studies in atrisk subpopulations [28]. Unfortunately, the ISDs are reimbursed in the USA only during the first three years post-transplant that is considered as known cause of non-compliance and consequent graft failure [29]. The European Society of Organ Transplantation is generally satisfied with the stricter criteria issued by the European Medicines Agency, proposing to regulate generic substitutions of critical dose drugs in vulnerable patient populations [30].

Finally, the physicians' responsibilities to their patients and the society could pose an ethical dilemma about the cost-effectiveness of the treatment [31]. In fact, in the public healthcare system, physicians should prioritize the treatment they consider most appropriate, not necessarily taking into consideration the need of a comparative cost-effectiveness [32]. Conversely, ISDs may bring savings to the national health budget that should be reinvested into clinical services in order to further improve the quality of patient care [33]. However, a comprehensive cost-efficient analysis should also involve the logistical issues towards anticipated drug shortages. Namely, the long-term reduction in the price of generic ISDs may be economical in short term, but may produce drug shortages in long-term since it becomes less profitable to manufacture these drugs [4]. 


\section{Conclusion}

The increased number of solid organ transplantation goes in line with the substantial proportion of the health care budget for ISDs. Thus, generic immunosuppressants could possible solve the problem if safely substituted for innovator products consistently receiving the same product, and the attending physicians endorse changes and impose enhanced therapeutic drug monitoring during transition to available ISD of choice. The substantial cost reduction need to be redirected into organ donation initiatives so that more patients can benefit from further increase in transplantation.

\section{REFERENCES}

1. Wolfe RA, Ashby VB, Milford EL, et al. Comparison of mortality in all patients on dialysis, patients on dialysis awaiting transplantation, and recipients of a first cadaveric transplant. N Engl J Med. 1999; 341(23): 1725-1730.

2. Barnieh L, Yilmaz S, McLaughlin K, et al. The cost of kidney transplant over time. Prog Transplant. 2014; 24(3): 257-62.

3. James A, Mannon RB. The Cost of Transplant Immunosuppressant Therapy: Is This Sustainable? Curr Transplant Rep. 2015; 2(2): 113-121.

4. Allard J, Fortin MC. Is it ethical to prescribe generic immunosuppressive drugs to renal transplant patients? Can J Kidney Health Dis. 2014; 1: 23.

5. Generic Drugs. Center for Drug evaluation and Research, U.S. Food and Drug Administration. [Cited 2015 July $13^{\text {rd }}$ ] Available from: http://www.fda.gov/downloads/Drugs/Development ApprovalProcess/SmallBusinessAssistance/ucm 1276 15.pdf.

6. Generic Drugs. World Health Organisation. [Cited 2015 July $13^{\text {rd }}$ ] Available from: http://www.who.int/trade/glossary/story034/en/.

7. Generic Drugs. The Free Dictionary. [Cited 2015 July $13^{\text {rd }}$ ] Available from: http://medicaldictionary.thefreedictionary.com/Drugs $\% 2 c+$ generic.

8. EFPIA. The Pharmaceutical Industry in Figures, key data 2014. [Cited 2015 July 13 ${ }^{\text {rd }}$ ] Available from: http://www.efpia.eu/uploads/Figures_2014_Final.pdf.

9. Meredith P. Bioequivalence and other unresolved issues in generic drug substitution. Clin Ther. 2003; (11): 2875-90.

10. Gondos A, Döhler B, Brenner H, Opelz G. Kidney graft survival in Europe and the United States: strikingly different long-term outcomes. Transplantation. 2013; 95(2): 267-74.

11. Roodnat JI, Hilbrands LB, Hené RJ, et al. 15-year follow-up of a multicenter, randomized, calcineurin inhibitor withdrawal study in kidney transplantation. Transplantation. 2014; 98(1): 47-53.

12. Gaynor JJ, Ciancio G, Guerra G, et al. Graft failure due to noncompliance among 628 kidney transplant recipients with long-term follow-up: a single-center observational study. Transplantation. 2014; 97(9): 925-33.

13. Couzi L, Moulin B, Morin MP, et al. Factors predictive of medication nonadherence after renal transplantation: a French observational study. Transplantation. 2013; 95(2): 326-32.

14. Tamargo J, Le Heuzey JY, Mabo P. Narrow therapeutic index drugs: a clinical pharmacological consideration to flecainide. Eur J Clin Pharmacol. 2015; 71(5): 549-567.

15. Verbeeck RK, Musuamba FT. The revised EMA guideline for the investigation of bioequivalence for immediate release oral formulations with systemic action. J Pharm Pharm Sci. 2012; 15(3): 376-88.

16. Lionberger R, Jiang W, Huang SM, Geba G: Confidence in generic drug substitution. Clin Pharmacol Ther. 2013; 94: 438-440.

17. van Gelder T, Gabardi S. Methods, strengths, weaknesses, and limitations of bioequivalence tests with special regard to immunosuppressive drugs. Transpl Int. 2013; 26: 771-7.

18. Waiser J, Slowinski T, Brinker-Paschke A, et al. Impact of the variability of cyclosporin A trough levels on long-term renal allograft function. Nephrol Dial Transplant. 2002; 17(7): 1310-7.

19. Spasovski G, Masin-Spasovska J, Ivanovski N. Do we have the same clinical results with Neoral and Equoral treatment in kidney transplant recipients? A pilot study. Transpl Int. 2008; 21(4): 392-4.

20. Borra LC, Roodnat JI, Kal JA, et al. High withinpatient variability in the clearance of tacrolimus is a risk factor for poor long-term outcome after kidney transplantation. Nephrol Dial Transplant. 2010; 25(8): 2757-63.

21. Sellarés J, de Freitas DG, Mengel M, et al. Understanding the causes of kidney transplant failure: the dominant role of antibody-mediated rejection and nonadherence. Am J Transplant. 2012; 12(2): 388-99.

22. Vítko S, Ferkl M. Interchangeability of ciclosporin formulations in stable adult renal transplant recipients: comparison of Equoral and Neoral capsules in an international, multicenter, randomized, open-label trial. Kidney Int Suppl. 2010; (115): S12-6.

23. Alloway RR, Sadaka B, Trofe-Clark J, et al. A Randomized Pharmacokinetic Study of Generic Tacrolimus Versus Reference Tacrolimus in Kidney Transplant Recipients. Am J Transplant. 2012; 12(10): 2825-2831.

24. Melilli E, Crespo E, Sandoval D, et al. De novo use of a generic formulation of tacrolimus versus reference tacrolimus in kidney transplantation: evaluation of the clinical results, histology in protocol biopsies, and immunological monitoring. Transpl Int. 2015; 28(11): 1283-90. 
25. Molnar AO, Fergusson D, Tsampalieros AK, et al. Generic immunosuppression in solid organ transplantation: systematic review and meta-analysis. BMJ. 2015; 350: h3163.

26. Johnston A. Equivalence and interchangeability of narrow therapeutic index drugs in organ transplantation. Eur J Hosp Pharm Sci Pract. 2013; 20(5): 302-307.

27. Harrison JJ, Schiff JR, Coursol CJ, et al. Generic immunosuppression in solid organ transplantation: a Canadian perspective. Transplantation. 2012; 93: 657-665.

28. Alloway RR, Isaacs R, Lake K, et al. Report of the American Society of Transplantation conference on immunosuppressive drugs and the Use of generic immunosuppressants. Am J Transplant. 2003; 3: 12111215.

29. Gordon EJ, Prohaska TR, Sehgal AR. The financial impact of immunosuppressant expenses on new kidney transplant recipients. Clin Transplant. 2008; 22: 738-748.

30. van Gelder T. European Society for Organ Transplantation Advisory Committee recommendations on generic substitution of immunosuppressive drugs. Transpl Int. 2011; 24: 1135-1141.

31. Minogue B. The two fundamental duties of the physician. Acad Med. 2000; 75: 431-442.

32. Maynard A. Health care rationing: doing it better in public and private health care systems. J Health Polit Policy Law. 2013; 38: 1103-1127.

33. Devaney A, Lee M. The use of generic immunosuppression for transplant patients: a UK perspective. Eur J Hosp Pharm. 2013; 20: 272-274.

\section{Резиме}

\section{ГЕНЕРИЧКИ ЛЕКОВИ - НАМАЛУВАЊЕ НА ТРОШОЦИТЕ И МОЖНОСТИТЕ ЗА ЗГОЛЕМЕН БРОЈ ТРАНСПЛАНТАЦИИ НА БУБРЕЗИ}

\section{Гоце Спасовски}

Клиника за нефрологија, Медицински факултет, Универзитет „Св. Кирил и Методиј“, Скопје, Р. Македонија

Бубрежната трансплантација е најдобриот тераписки модалитет во споредба со дијализата, иако пациентите се обврзани да примаат доживотен медицински третман со имуносупресивни лекови (ИСЛ) за превенција од отфрлање на графтот. Таквиот имуносупресивен третман може да чини многу и е асоциран со многу несакани ефекти. Трошокот се смета за еден од главните ограничувања за зголемување на бројот на трансплантации, и употребата на генерички ИСЛ може да ја намали севкупната цена на трансплантација и да ја зголеми можноста за нејзин понатамошен развој.

Идеалниот ИСЛ треба да има сигурносни маргини помеѓу токсичната и тераписката доза, и да го превенира развојот на акутното или хронично отфрлање на трансплантираниот бубрег. Ова е особено важно за лекови со „тесен тераписки индекс“ (ТТИ), при што мали разлики во дозата или концентрацијата доведуваат до дозно и концентрациски зависен, сериозен тераписки неуспех и/или несакани ефекти од лековите. Генерички лек со ТТИ се одобрува ако е во 90\%-112\% во зоната под крива на фармакокинетиката на оригиналниот лек исполнувајќи ги строгите критериуми на фармацевтска еквивалентност и биоеквивалентност. Секој генеричен лек треба да се докаже дека е биоеквивалентен на иновативниот продукт, а не на другите генерички продукти поради веројатноста од генеричко „пренасочување“. Така, генеричките ИСЛ може да се економски примамливи, но, теоретски, може да се потенцијално ризични за трансплантираните пациенти. Таквите ризици може да се редуцираат ако се направат долгорочни студии кои ќе покажат исплатливост на генеричките ИСЛ кај de novo и превалентни трансплантирани пациенти за секој нов генерички лек.

Како заклучок, зголемениот број трансплантации на солидни органи оди заедно со зголемената здравствена потрошувачка за ИСЛ. Генеричките имуносупресиви би можеле да бидат можно решение ако се сигурни во замената на иновативните продукти или други генерички лекови од избор. Значајната редукција на трошок треба да биде пренасочена кон иницијативи за орган-донација така што повеќе пациенти можат да имаат бенефит од понатамошното зголемување на бројот на трансплантации.

Клучни зборови: бубрежна трансплантација, имуносупресивен третман, генерички лекови, тесен тераписки индекс. 